DEMOGRAPHIC RESEARCH

VOLUME 43, ARTICLE 26, PAGES 745-778

PUBLISHED 4 SEPTEMBER 2020

https://www.demographic-research.org/Volumes/Vol43/26/

DOI: 10.4054/DemRes.2020.43.26

Research Article

"Everyone tries to avoid responsibility" The attenuating role of financial obligations in fertility change among Yorùbá farmers of southwestern Nigeria

Fausat M. Ibrahim

(C) 2020 Fausat M. Ibrahim.

This open-access work is published under the terms of the Creative Commons Attribution 3.0 Germany (CC BY 3.0 DE), which permits use, reproduction, and distribution in any medium, provided the original author(s) and source are given credit.

See https://creativecommons.org/licenses/by/3.0/de/legalcode. 


\section{Contents}

1 Introduction $\quad 745$

2 The necessity of interpreting African demographic motivations $\quad 747$

3 A succinct ethnography and the socioeconomic character of the 749

Yorùbá people

3.1 Religion among the Yorùbá 750

3.2 İwà and ọọlúàbí 751

3.3 Yorùbá lineage and its consequences for the economic cost of 752

$\begin{array}{lll}3.4 & \text { Fertility and socioeducational profile } & 753\end{array}$

$4 \quad$ Methods $\quad 754$

$\begin{array}{lll}4.1 & \text { Study design } & 754\end{array}$

$\begin{array}{lll}4.2 & \text { Study participants } & 754\end{array}$

$4.3 \quad$ Community entry 754

4.4 Data collection and management $\quad 755$

4.5 Data analysis $\quad 756$

4.5.1 Preparation and organisation of data 756

4.5.2 Review and exploration of data $\quad 757$

4.5.3 Creation of initial codes $\quad 757$

4.5.4 Revision of codes and combination into themes 757

4.5.5 Cohesive presentation of themes 757

$\begin{array}{lll}4.6 & \text { Ethical considerations } & 758\end{array}$

$5 \quad$ Findings 758

5.1 Basic demographic characteristics of participants 758

5.2 Financial obligations as an impediment in fertility behaviour $\quad 759$

5.3 Scriptural justification for pecuniary considerations in childbearing $\quad 759$

5.4 Meeting financial obligations to children as a prerequisite of the $\quad 760$

$\begin{array}{lll}5.5 & \text { Children's education as a check against increasing fertility } & 761\end{array}$

5.5.1 Civilization-induced need for formal education 763

5.5.2 The dynamic of public versus private school in the educational 764 constraint on increased fertility

5.6 Women's financial obligations and fertility reduction 765

5.6.1 Domestic economic responsibilities 765

5.6.2 Dearth of support from husbands 766

$\begin{array}{lll}\text { 5.6.3 Husband-related obligation } & 766\end{array}$

$\begin{array}{lll}6 & \text { Discussion } & 767\end{array}$

$\begin{array}{lll}7 & \text { Conclusions } & 772\end{array}$

References 


\title{
"Everyone tries to avoid responsibility" The attenuating role of financial obligations in fertility change among Yorùbá farmers of southwestern Nigeria
}

\author{
Fausat M. Ibrahim ${ }^{1}$
}

\begin{abstract}
BACKGROUND

Demographic discourse is replete with concern over Africa's high population, with implications that are disturbing for African culture and development. However, the gap in demographic knowledge creation and other unequal socioeconomic dynamics impede the development of emic African demographic perspectives. Moreover, there is a supposition that population growth is in compliance with the demand for children for farming purposes in Africa.
\end{abstract}

\section{OBJECTIVE}

The objective of this work is to explore fertility motivations among Yorùbá farmers, while being sensitive to generational and gender specificities.

\section{METHODS}

This is qualitative research that explores, interprets, and describes the narratives of the participants. The data were collected from 12 focus group discussions, 24 in-depth interviews, and 8 key-informant interviews, and analysed inductively.

\section{RESULTS}

The results find an extensive pecuniary motivation for fertility reduction. The economic cost of raising children hinders fertility in southwestern Nigeria such that it is converging with the global low fertility regime. Anxiety regarding the inability to meet the financial obligations of childbearing is also reflected in scriptural justifications for pecuniary considerations regarding fertility change. Women farmers are found to be especially affected by economic demands in fertility change.

\section{CONTRIBUTION}

The paper expounds the rational and adaptive character of fertility in a sub-Saharan African culture and vindicates the Caldwellian theory of wealth flows. The findings show that in this population attitudes and experiences are optimal for low fertility.

\footnotetext{
${ }^{1}$ Federal College of Forestry, Forestry Research Institute of Nigeria, Ibadan, Nigeria.

Email: fausatibrahim@gmail.com.
} 


\section{Introduction}

The demographic transition is a prominent theory in the social sciences that has achieved "enduring and widespread circulation" (Carlson 2019: 7). It postulates that societies transition from a pre-modern era of high birth and death rates to a post-modern era of low birth and death rates. This transition is essentially represented as development. Dyson (2010) asserts that declining birth and death rates are both central to fertility transition and characterise the concept of development. Similarly, Galor (2004) affirms that the demographic transition occurred widely across the globe during the $20^{\text {th }}$ century and that this indicates progress towards lasting economic growth.

The fertility regime in sub-Saharan Africa is exceptional. Although there is great diversity in this region (Cleland, Onuoha, and Timæus 1994), fertility has remained high compared with every other world region. Africa's demographic transition started "later" 2 than in other non-African developing countries (Bongaarts 2017: 54, italics in original). In an "ageing world" the African population is "uniquely ... younger" (Gitahi 2017: 96). Projections by the United Nations Population Division (2017) show that in $205026 \%$ of the global population will be in Africa and in $210040 \%$ will be in Africa. Currently, $17 \%$ of the world's population is in Africa.

Demographic transition theory presupposes that socioeconomic development triggers fertility transition, which is characterised by increased education, industrialisation, and urbanisation. It could therefore be supposed that sub-Saharan Africa's population situation is a consequence of its poor economic indices. Thirty of the forty-two mainland African countries are categorized as 'least developed', as opposed to a total of fourteen other countries from all other regions of the world (Cleland and Machiyama 2017). The path to socioeconomic development - the transition from pre-modernity to post-modernity that is central to demographic transition - is associated with increasing rationality in fertility choices. Caldwell (1976) asserts that the demographic transition theory predicts fertility decline in traditional societies as modernisation, industrialisation, and rationality emerge. In essence, traditional pre-transitional societies are yet to fully enjoy fertility change because they not yet rational. Further,

... the criteria employed (in the definition of rationality) are highly ethnocentric and are laden with Western values. It is assumed that it is rational for a man or a couple to maximize the expenditure on the individuals in his or their nuclear family; but there are many ... non-Western societies in which there is greater pleasure in spending on some relatives outside the nuclear family (adult brothers for instance) than on some within it, and in

\footnotetext{
${ }^{2}$ Bongaarts (2017) concurrently concluded that Africa's demographic transition was "earlier".
} 
which children are happier to spend on parents than are parents on children. Obviously, the fundamental choices are social ones and economic behavior is rational only insofar as it is rational within the framework established by social ends. What demographic transition theory has always regarded as rational are primarily Western social ends with economically logical steps to maximize satisfactions given those ends.

(p. 326, first bracket mine).

The theory accuses traditional, yet-to-transit, or poorly transiting societies of being "brutish and superstitious" (Caldwell 1976: 324), so the culture or the superstructure perpetrates high fertility. Caldwell (1976) posits that "demographic transition literature is full of references not to the behavior or reactions of such people but to attitudes, beliefs, traditions, and irrationality" (p. 325, italics mine). The theory fails to consider "reactions and accommodations" to peculiar economic situations. Hence, in his criticism, Caldwell (1976) asserts that

there are only two types of fertility regime: [...] one where there is no economic gain to individuals from restricting fertility; and the second where there is often or eventually economic gain from such restriction. In both situations behavior is not only rational but economically rational (p. 322).

This Caldwellian theory of wealth flows recognises the rationality and adaptability of human motivations in compliance with social situations. By extension, Caldwellian theory counts individual and social features when explaining fertility change. This paper argues that African demographic motivations will benefit from the exploration of these individual and social specificities in fertility matters.

\section{The necessity of interpreting African demographic motivations}

African culture is certainly in tune with pronatalist philosophy. In African culture fecundity is applauded. For instance, the Yorùbá people of Nigeria say olomo lo laye (one who has children owns the world) and olomo là (the bearer of children has prospered). However, this emphasis on children may well be connected with the ultimate human necessity of adapting to social circumstances, as recognized by the Caldwellian theory of wealth flows. Unfortunately, the exploration and exposition of the motivations behind African demographics is limited. In fact, this limitation is pervasive in social science literature in general and not just in demography. Omobowale (2013) asserts that "the exposure of African social science scholarship to the global 
academy has been dependent and peripheral. Its peripheral nature is not unconnected to the fact that social science theories and methodology are dependent on Western discoveries and scholarship. Groundbreaking paradigmatic postulations are hardly advanced from Africa. Even when they are advanced, such paradigmatic postulations hardly gain international relevance, and they are largely spurned by the local scholarly public..." (p.3). Beyond this, the dearth of expositions of African motivations in the demographic literature is also a reflection of a major limitation of demography as a discipline. Demography is a science, and is therefore replete with positivistic and nomothetic endeavours. Kertzer (1997) acknowledges "the problem of culture" in demography by questioning the features of "a satisfactory explanation of demographic behaviour":

For most demographers, the answer to this question - if only implicitly - is a mathematical equation, in which the demographic behaviour in question (fertility, age at marriage, etc.) is the left-hand term (i.e., the dependent variable) and the factors that influence that behaviour (education, occupation etc.) are the right-hand term (i.e., the set of independent variables). Such models are typically used these days at the micro level to model (i.e., explain) the demographic behaviour of individuals. However, forms of these models are also used for larger aggregates, that is, for identifiable geographical or other units. Of course, there are many ways in which sophisticated demographers may complicate such models, but this is what they boil down to (p. 137).

Cross-sectional studies examining differential fertility are abundant. The consequence of this is that the historical perspective is not accounted for and explanations are then built around transitory factors (Cleland and Wilson 1987). The positivist tradition has engendered the development of its antithesis, anti-positivism, because human social behaviour cannot be successfully objectified like everyday matters. Demographers are beginning to appreciate this position. For instance, in their pivotal article titled Disciplining Anthropological Demography, Coast, Hampshire, and Randall (2007: 495) argue that "disciplinary knowledge is, of itself, a social product created and shaped by its disciplinary home". They therefore advocate for more interpretive demographic endeavours because "knowledge cannot be taken out of its context and be compared with knowledge from another context" (p. 505). Coast, Hampshire, and Randall (2007) note the sluggish pace at which demography responds to criticisms of the positivistic method, while not disputing the relevance of demography's quantitative character. Caroline Bledsoe's (2002) seminal work is a quintessential example of the great benefits accruable from a blend of quantitative and qualitative approaches in demography. Bledsoe (2002) develops a contingency logic to 
make sense of the peculiarities of contraceptive use in Gambia, which parallels the western rationale of using contraception for limiting and spacing births. Bledsoe's (2002) employment of the anti-positivistic or interpretive tradition that advances the idiographic nature of knowledge unearthed the astonishing practice of Gambians' use of contraceptives to ultimately improve birthing capacity rather than otherwise. Cooper's (2019) recent account of sociohistorical motivators of fertility in Niger, the country with the world's highest TFR, affords richly wholistic and specific explanations of high fertility. Both reproduction and provision of daily family sustenance are obligatory, and perpetuate cultural and familial legacies while securing the continued existence of lineages. Inability to rise to the occasion is tantamount to being socially dead. This creates fear of and shame attributed to infertility, underscoring Cooper's "affective determinants of fertility" (2019: p. 28, italics in original). Yet this pro-fertile social reproduction set-up is in response to specific Sahelian ecology: experiences of slavery and colonialism, the expansion of Islam, and French military rule, among other structural factors.

When the interpretive paradigm is employed the diversity of thought structures is laid bare and the voices of less vocal groups like Africans are echoed in mainstream circles. No wonder several scholars, including Gareau (1988), have called for a resistant African social science that wrestles with western domination of social science scholarship. Gareau (1988) considers the history of social science as reflective of the development of the international economic order. He promotes the use of approaches to domesticate foreign theories - approaches that tends to contextualize, thereby making theories more applicable to local circumstances.

In this light, this study is designed to explore African demographic motivations. More specifically, this article is part of a larger study designed to explore the motivations behind fertility among Yorùbá farmers, while being sensitive to generational and gender specificities. This report focuses on the principal attenuating role in fertility change of financial obligations. The context of Yorùbá society is described below.

\section{A succinct ethnography and the socioeconomic character of the Yorùbá people}

An understanding of the ethnography and socioeducational background of the Yorùbá people is necessary to appreciate their current demographic orientation. This section presents a brief history of the Yorùbá character, religion, and lineage and the implications for child welfare, demography, and education. 
Before the $19^{\text {th }}$ century a conglomerated Yorùbá did not exist as it does today. The peoples with different Yorùbá dialects such as the Ijebu, Ifẹ, and Ọyọ existed as independent polities. This showcases the heterogeneity of this ethnic group (Lawal 2001), but there is a lot of evidence supporting the homogeneity of the Yorùbá; for example, the shared origin myth that the Yorùbá people are descendants of Odùduwà (Omobowale 2008). The rise of homogeneity among the Yorùbá sub-groups was facilitated by the dynamics of the internationalisation of political and economic forces, which favours generalisation. Contemporary popular music also plays an indelible role in the creation of Yorùbá identity (Waterman 1990).

The Yorùbá people are largely located in the six states of southwestern Nigeria. The southwestern region is one of Nigeria's six geopolitical zones. Approximately $18 \%$ (Okolie et al. 2018) of Nigeria's population of 201 million (United Nations Population Division 2019) are Yorùbá.

\subsection{Religion among the Yorùbá}

The social character of the Yorùbá people is intertwined with their culture and religion, which are inextricable. Existence is seen as a journey; hence, the Yorùbá people say ayé lojà, orun nilé (the world is the market, the heaven is home). Adogame (2000) explains that orun (heaven) is the dwelling of transcendental beings, while ayé (the world) represents the earth or human abode. Orun and ayé are sacred, given the belief that there is an abundance of ebora (spiritual beings) in the world, who rightly belong to orun but also exist and influence world dynamics. Olódùmarè/Olorun, the most Supreme Being, created the world and the heavens. Olódùmarè created an abundance of Orìsàs (gods). The Orìsàs are ministers of Olódùmarè, many of which are compassionate, and some of which are hostile (Drewal, Pemberton III, and Abiodun 1989). Human habitation is therefore conceived as being a playing field of contradictory powers (Adogame 2000; Barber 1981). The hostile powers include witches. The people worship different Òrìsàs. Yorùbá Orì̀à worship is open and devotees can experiment with new perspectives. This openness had implications for the wide acceptance of Islam and Christianity at their introduction into Yorùbá society (Barber 1981).

Ifá is the Yorùbá divination system, which is the most sophisticated of African divination systems (Capone 2018). According to Abímbọlá (2004: xi), "àgbà òrìsà ni Ifá jẹ", meaning that Ifá is an elder among the Orì̀às. Yorùbá oral philosophies are of varying categories, including the Ifá literary corpus that occupies a central position in the Yorùbá frame of reference (Abímbọlá 1975; Harris 1992). "Ifá is seen as a practice which embodies Yorùbá beliefs, history, sociology and ecology. ...Yorùbá practices 
and cultural paradigm could be discerned, studied and appreciated from many Ifá verses" (Olademo 2009: 49). The custodians of Ifá are the Babaláwo (male) or Iyanifa (female), who pass through scrupulous training in the form of memorising the Odùs of Ifá (Olademo 2009). Although Ifá has lost its stronghold in the religious and cultural life of the Yorùbá due to the massive social changes that Yorùbá society has experienced and the introduction of monotheistic religions, it is still very vital to traditionalists and to Christians and Muslims who consult it clandestinely (Omobowale 2008). Most Yorùbá now identify as Muslim or Christian, which are considered 'civilized' (Olurode and Olusanya 1994: 92). Ostien (2012) computed the distribution of religions in the current Nigerian geographical regions using 1952 and 1963 census data (these two censuses were the last to include religion as an item in the census surveys because of the controversies that trail censuses in Nigeria). In 1952 in the southwest $32.8 \%$ identified themselves as Muslims, 36.9\% as Christians, and $30.3 \%$ as 'other'. By 1963 the percentage of Muslims was 35.7, Christians were 49.9\%, and 'others' were $14.4 \%$. The southwest region is very diverse and which religion dominates may depend on the context. Yorùbá people are inherently traditional when it comes to supernatural matters, even as they profess Christianity or Islam (Olurode and Olusanya 1994). Hence, they believe in the unseen, "in an interface of the visible and invisible, the tangible and intangible, the known and unknown (which) makes it evident that the act of looking and seeing in Yorùbá culture is much more than a perception of objects by use of the eyes" (Lawal 2001: 521, bracket mine).

\section{2 İwà and ọmolúàbí}

The concepts of ìwà (character) and omolúàbi (the good person) occupy a transcendent position in the ontological dynamics of the Yorùbá, and they go hand in hand, as only those who have ìwà or its equivalent, ìwà rere, can be said to be omolúàbí. In a lexical sense, iwà literarily means 'to exist', and it also means character, a situation arising from a colloquial employment of the lexical connotation (Abímbọlá 1975: 393). An omolúàbi is an ideal person, who "has been educated to respect old age, to be loyal to one's parents and local traditions, to be honest in all public and private dealings, to be devoted to duty and be ready to assist the needy and the infirm, to be an epitome of sympathy, sociability, courage and itching desire for work and many other desirable qualities" (Adebisi 2016: 34). Awoniyi (1975) describes the omolúàbi ideology as the philosophy of traditional education in Yorùbáland. According to Awoniyi (1975):

That the African traditional society has something to offer educational theory and practice is brought out lucidly in its traditional educational pattern through 
a combination of precepts and oral literature [...] the principles of Yorùbá education are based on the concept of omọlúàbí. The end product of education is to make an individual an omọlúàbí. To be an omolúàbi is to be of good character in all its ramifications (p. 364, italics mine).

Abímbọlá (1975) asserts that "a man's ìwà is what can be used to characterize his life especially in ethical terms" (pp. 393-394). He further writes that "Olódùmarè himself is the embodiment of good character. He therefore expects human beings to have good character as well. It is a sin against the divine law of Olódùmarè for anybody to deviate from the path of good character.... this then, is the reason why the Yorùbá regard good character as the essence of religion" (p. 416).

The concept of iwà is the active ingredient in the production of omolúàbi, and scholars count this as the focus of the traditional Yorùbá educational system (Harris 1992). Traditional Yorùbá education is built with the concept of omolúàbi: "a desirable personality type appropriate for social approval is described by such labels as omolúàbi (personable)" (Elegbeleye 2005: 88). Hence, the concepts of ìwà and omolúàbi go hand in hand, and together they motivate traditional Yorùbá education, which aims to weave children harmoniously into society (Awoniyi 1975).

\subsection{Yorùbá lineage and its consequences for the economic cost of childbearing}

The Yorùbá lineage, idilé, encompasses individuals of common ancestry through the male line. Hence, Yorùbá society is patriarchal. Descent is a function of the agnatic (from agnate, descendants of a man) line. Segmentation is the fundamental basis of systemising the Yorùbá lineage (Afonja 1981). Every male is the prospective creator of a segment, if he is not already. Even though Yorùbá society is patrilineal, this does not rule out the institution of rights and obligations to kin related through the mother. However, maternal affiliation is not a foundation for constituting corporate social groupings. The baálè (literarily, father of the house), the most senior male member of the lineage, assumes leadership of the group. His directive-giving and juridical influence is well recognized among members. Lineage is the normal means of expression among the elements of the society. Given the massive social change occasioned by globalisation, kinship bonds have become weaker.

In Yorùbá culture, children belong to their fathers absolutely (Fadipe 1970). Strictly speaking, among the Yorùbá all the financial costs of bearing children also belong to men. Such economic cost is automatically the responsibility of other members of the father's lineage (including female members), before mothers become liable for this responsibility. This male-provider model is, however, more culturally ideal than 
what obtains in reality. In an article entitled 'Bargaining with Patriarchy', Kandiyoti (1988) discusses the continuum of women's situation of relative autonomy as evidenced in some parts of sub-Saharan Africa as opposed to the more male-headed 'classic patriarchy' in parts of Asia and the Middle East. Citing examples from Yorùbá society, Kandiyoti (1988) expounds that in the former circumstance, men's obligation to provide for their wives is poorly met/fulfilled in reality, even though such obligation is normative. Women pervasively assume responsibility for their own welfare and their children's, including educational expenses, while men render their quota in varying proportions. Yorùbá women have been notably enterprising and independent since the pre-colonial and colonial periods (Renne 1993; Caldwell, Orubuloye, and Caldwell 1991; McIntosh 2009). McIntosh (2009) notes that elderly senior wives in typical polygamous settings are able to rally family services to "accumulate wealth and greater authority vis-à-vis their husbands and other relatives" (p. 88). Thus, women are bound to contribute significantly to the economic cost of raising their children.

\subsection{Fertility and socioeducational profile}

Although Yorùbá women typically express their desire for abundant children, their average fertility is lower than in other Nigerian and West African societies (McIntosh 2009). While the highest total fertility rate in all the Nigerian regions is 6.6 children per woman, the southwestern region of the Yorùbá people currently has the lowest total fertility rate of 3.9 children (National Population Commission 2019). The latest Nigerian Demographic and Health Survey also reports that the southwest region has the highest total demand for family planning (for limiting and spacing children) at $57.4 \%$; the lowest across all regions is $21.1 \%$ (ibid). The average Nigerian household size is 5.5 and the highest household size in the six Nigerian geo-political zones is 7.9: the current average household size in southwestern Nigeria is the lowest at 3.2 (National Bureau of Statistics 2019). The southwest also has the second highest share (27.7\%) of femaleheaded households of the six regions, the highest being $32.4 \%$. The southwest has the highest literacy rate of $81.7 \%$, the lowest rate being $51.2 \%$ (ibid). The southwest region has the second highest proportion of individuals who completed secondary education (27.1\%); the highest across all regions is $27.3 \%$. The region recorded the highest percentage of individuals with post-secondary education (14.3\%); the lowest across all regions is $2.7 \%$ (National Bureau of Statistics 2019). Thus, the southwest region contributes positively and significantly to Nigeria's socioeducational and demographic profile. The fertility change among the Yorùbá recorded in this study is therefore not so astonishing. 


\section{Methods}

\subsection{Study design}

The study design is exploratory, narrative, and descriptive. Participants' narratives were explored, interpreted, and described.

\subsection{Study participants}

The study population was the Yorùbá people of southwestern Nigeria; Yorùbá farmers were primarily targeted. Farmers were targeted for several reasons: high fertility is traditionally justified for productive purposes, and the traditional occupation is largely farming. Rural communities have the reputation of being great contributors to population growth, and more 'traditional' people live in the rural areas, where most people are still farmers. The states of Oyọ and Ọsun were randomly selected from the six states of Southwestern Nigeria, and the rural communities of İgbòho and Gbòngán were randomly selected from these two states. The typical occupation of people in these study sites is farming but many people diversify into the non-farm economy.

\subsection{Community entry}

The process of entering the community at Gbòngán was eased by the king of the community, whose support was sought and accessed without difficulty. The king was learnèd, and he facilitated reaching out to other stakeholders among the farmers. At İgbòho, farmers' associations were reached initially, and their leaders made it easy to access farmer groups. These leaders were lavish in providing the required support. A farmer-based reconnaissance survey was conducted in the two communities to identify prospective participants, who were screened to ensure they met the inclusion criteria. Upon reaching farmers and introducing the study to them, the inclusion criterion was simply the readiness to participate in the study. In some instances, the criteria were their sex and their generation, informed by their chronological age. Where more people met the criteria than required, the prospective participant considered to be more willing was selected. Where this was not obvious, a coin was tossed to determine who participated. Participants were appreciated by offering them a small gift of $400 \mathrm{~g}$ of detergent powder. 


\subsection{Data collection and management}

Data collection featured twelve focus group discussions (FGDs). During group discussions there were opportunities for submissions to be refuted or supported by other group members. Hence, the FGDs were conducted to generate consensus as part of the data production process. Twenty-four in-depth interviews (IDIs) were also conducted. IDIs are more person-focused and anonymity-friendly, thereby providing space for participants to delve into their personal experiences. IDIs were therefore conducted to unearth participants' experiential world. Further, eight key-informant interviews (KIIs) were conducted. Key informants were individuals possessing specialised information by virtue of their leadership position. The KIIs were conducted among heads of farmers' groups and other community leaders.

The FGDs were conducted first in each community. Some prospective participants who demonstrated readiness to participate but could not be accommodated in group discussions were asked to grant interviews. Other prospective participants who were available for group discussions at times that such discussion could not be conducted were also asked to grant interviews. Participants who were less expressive during the discussions were approached and asked to grant interviews. One hundred and twentyeight participants participated in the study. The pattern of participant selection is shown in Table 1 below. The fundamental question that participants were asked was what motivates their (Yorùbá farmers) fertility, including lived experiences illuminating their fertility decisions. Subsequent questions depended on participants' initial responses. This article is a constellation of the pecuniary-related data resulting from that fundamental question. The data were interrogated for differences across generation and gender. Participants were probed to generate further questions and to elucidate their responses. They were prevented from digressing too much into non-related issues. Digital audio devices were used to record the discussions and interviews to ensure that no data were lost. Information was collected regarding participants' educational achievement, religion, and marital status. 
Ibrahim: The role of financial obligations in fertility change among Yorùbá farmers of southwestern Nigeria

Table 1: Pattern of participant selection

\begin{tabular}{|c|c|c|c|c|c|}
\hline $\begin{array}{l}\text { Data collection } \\
\text { method }\end{array}$ & Generations & Gender & İgbòho & Gbòngán & Total \\
\hline \multirow{6}{*}{$\begin{array}{l}\text { Focus group } \\
\text { discussions* }\end{array}$} & \multirow{2}{*}{$\begin{array}{l}\text { Younger generation }(<29 \\
\text { years) }\end{array}$} & Male & 1 & 1 & 16 \\
\hline & & Female & 1 & 1 & 15 \\
\hline & \multirow{2}{*}{$\begin{array}{l}\text { Middle-age generation (30-59 } \\
\text { years) }\end{array}$} & Male & 1 & 1 & 16 \\
\hline & & Female & 1 & 1 & 17 \\
\hline & \multirow[t]{2}{*}{ Older generation ( $>60$ years) } & Male & 1 & 1 & 18 \\
\hline & & Female & 1 & 1 & 14 \\
\hline Total & & & 49 & 47 & 96 \\
\hline \multirow{6}{*}{$\begin{array}{l}\text { In-depth Interviews } \\
\text { (IDIs) }\end{array}$} & \multirow{2}{*}{$\begin{array}{l}\text { Younger generation }(<29 \\
\text { years) }\end{array}$} & Male & 2 & 2 & 4 \\
\hline & & Female & 2 & 2 & 4 \\
\hline & \multirow{2}{*}{$\begin{array}{l}\text { Middle-age generation (30-59 } \\
\text { years) }\end{array}$} & Male & 2 & 2 & 4 \\
\hline & & Female & 2 & 2 & 4 \\
\hline & \multirow[t]{2}{*}{ Older generation ( $>60$ years) } & Male & 2 & 2 & 4 \\
\hline & & Female & 2 & 2 & 4 \\
\hline Total & & & 12 & 12 & 24 \\
\hline \multirow{6}{*}{$\begin{array}{l}\text { Key Informant } \\
\text { Interviews (KIIs) }\end{array}$} & \multirow{2}{*}{$\begin{array}{l}\text { Younger generation }(<29 \\
\text { years) }\end{array}$} & Male & - & - & - \\
\hline & & Female & - & - & - \\
\hline & \multirow{2}{*}{$\begin{array}{l}\text { Middle-age generation (30-59 } \\
\text { years) }\end{array}$} & Male & 1 & 1 & 2 \\
\hline & & Female & 1 & 1 & 2 \\
\hline & \multirow[t]{2}{*}{ Older generation (> 60 years) } & Male & 1 & 1 & 2 \\
\hline & & Female & 1 & 1 & 2 \\
\hline Total & & & 4 & 4 & 8 \\
\hline Grand total & & & 65 & 63 & 128 \\
\hline
\end{tabular}

Note: *An FGD consisted of 7 to 9 participants.

\subsection{Data analysis}

The data were analysed according to the following process.

\subsubsection{Preparation and organisation of data}

The analysis of data began as soon as the data were collected. It was translated into English because most participants spoke Yorùbá. Help was sought from Yorùbá academics to translate difficult Yorùbá words. Transcription was also concurrent. Data immersion through reading the transcripts gave a general understanding of participants' expressions. Data from each interview and group session were documented in separate Microsoft Word documents. 


\subsubsection{Review and exploration of data}

The transcripts were uploaded into NVivo. Reading and re-reading continued at this stage. The purpose of the continuous reading was to become increasingly familiar with the data. Notes about thoughts, ideas, or questions were created in NVivo - in other words, memos were created. Each source document was created as a case to ascribe them with an identity. The documents were ascribed labels within the subcategories of gender, generation, and data collection method. A word count identified the words that occurred most frequently in the transcripts. This suggested concepts and ideas to look out for during coding.

\subsubsection{Creation of initial codes}

NVivo was used to code the data and formally organise them to reveal themes and essential ideas. Initial codes were created in line with both specific objectives and emerging ideas. Subsequently, codes were created inductively, i.e., based on data content. Ideas in the data determined the codes that were developed. Decontextualization through excessive data fragmentation was prevented.

\subsubsection{Revision of codes and combination into themes}

Potential themes or relationships between categories were identified using the developed codes and memos. Recurring themes, language, and ideologies became more apparent at this stage. Coding query and matrix coding query were run to examine how emerging themes were affected by data collection method (FGD, IDI, KII), the participant's generation (younger, middle-age, older), and the participant's gender (male, female). The coding queries enabled the comparison of contributions of participants from the different sub-groups of gender, generation, and data collection method in theme content.

\subsubsection{Cohesive presentation of themes}

The themes that emerged were presented and interpreted. In other words, the stories accrued from data were told in a cohesive manner. 


\subsection{Ethical considerations}

Research assistants were trained to treat participants with the utmost respect, especially since Yorùbá culture particularly values respect for elders. Details of the study were read to prospective participants. They were assured that no risks were involved. Anonymity was strongly guaranteed, and prospective participants were made to appreciate that they had the power to bring data collection to a halt at any time. Their informed consent was obtained and documented. The proposal for this study was submitted to the Institutional Review Board of the Faculty of Social Science, University of Ibadan for ethical approval and was approved (assigned number UI/SSHREC/ 2018/0030).

\section{Findings}

Five themes and five sub-themes/topics emerged from the data regarding the attenuating role of financial obligations in fertility change. These are presented after the presentation of participants' demographic characteristics.

\subsection{Basic demographic characteristics of participants}

The participants' mean age was $46.07 \pm 19.48$. Most were married, and about one in four participants had no formal education. They were largely Muslim, and about one in five practiced traditional religion. The basic demographic characteristics of the participants are shown in Table 2.

Table 2: $\quad$ Basic demographic characteristics of participants $(N=128)$

\begin{tabular}{llc}
\hline Sociodemographic profile of participants & & $\mathbf{n}(\%)$ \\
\hline Marital status & Single & $9(7.0)$ \\
Educational achievement & Married & $119(93.0)$ \\
& No formal education & $35(27.3)$ \\
& Primary School Certificate & $33(25.8)$ \\
& Secondary School Certificate & $45(35.2)$ \\
Religion & Tertiary Certificate & $15(11.7)$ \\
& Islam & $68(53.1)$ \\
& Christianity & $36(28.1)$ \\
& Traditional & $24(18.8)$ \\
\hline
\end{tabular}




\subsection{Financial obligations as an impediment in fertility behaviour}

Among the participants, pecuniary challenges were a major theme underlying fertility reduction. The participants' thoughts and practices strongly reflected a change from pro-natal philosophy owing to financial constraints. Two Yorùbá concepts, bùkáátà (responsibilities) and ojúse (duties) were very much reflected in the data. A group discussant stated:

Bùkáátà (responsibilities) is what is limiting the desire to have children these days. No one wants to have children and have them suffer (Male, middleaged.).

An in-depth interviewee buttressed this position, stating that responsibilities limited his desire for additional children:

I have no personal reason to stop having children except that I do not have money to take care of them (Male, middle-aged).

The role played by financial handicaps in having more children was very palpable in participants' contributions. In explicating the concept of bùkáátà, a key informant regarded fertility as a divine blessing that is limited in the light of the accompanying responsibilities. According to him:

God endows man with fertility but everyone tries to avoid responsibility (bùkáátà ni kálukú n'sá fún) (Male, older generation).

\subsection{Scriptural justification for pecuniary considerations in childbearing}

In a very interesting twist on the subject of financial obligations and fertility decisionmaking, participants reached for religious injunctions to support their position. This scripture-scouting tendency was not peculiar to any religious affiliation. Several participants cited scriptural evidence to justify pecuniary considerations regarding fertility reduction. A group discussant stated:

Without the need to cater for children, there is no limit to what number of children to have. The Quran also says that children and wealth are burdens. If one does not take care of them, they will end up being burdens for one on the day of judgement (Male, middle-aged). 
Ibrahim: The role of financial obligations in fertility change among Yorùbá farmers of southwestern Nigeria

A group discussant presented scriptural justification and lived experience as follows:

The Bible says that good parents will leave inheritance for their children and their children's children. I like to have many children but I ask myself what I would be able to leave for my children. I am concerned about how I would be able to take care of them. The size of one's pocket goes a long way to determine the number of children one would have. I have two boys already. If God blesses me beyond my current situation, I will surely have more children (Female, younger generation).

While reacting to the subject of religious injunctions and fertility reduction, an indepth interviewee stated:

If God grants us children and we refuse to fulfil our responsibilities to them, it is $a \sin$ (Female, middle-aged).

A key-informant elucidated the idea that the scriptures enjoin man to have lots of children. This is the traditional orientation regarding religion and fertility. However, this interviewee concomitantly asserted the relevance of scriptural injunction when considering the financial implications of increased fertility.

The word of God did not place limitations on the number of children we should have. In the book of Sam, God said that blessed be the man whose pocket is full of children. God gives children. He gives as He desires, it is not something where you can just decide the number you want. The Bible says that children are the inheritance of God. However, the issue of finance causes dilemmas because the same Bible says that woe unto those who are granted children but do not care for them (ègbé ni fún ẹni tí a fún lomo tío tọ). The Bible further says that a man that fails to fulfil responsibilities to his family is worse than an infidel. A rope should be tied to the neck of such a man and he is to be thrown in a well (Male, older generation).

\subsection{Meeting financial obligations to children as a prerequisite of the child's good character}

Most participants justify fertility reduction on the basis of the fear that inability to meet provisional obligations will hinder a child's good character. There is underlying anxiety 
that children will not turn out well without adequate financial provision. This is understandable in a culture that places responsibility for a child's conduct on the child's family, including his or her extended family. A group discussant stated:

The totality of responsibilities makes giving birth to many children difficult for people today and that is why it is advised to give birth to children we can cater for in order to make them responsible to themselves and society. Many wayward children today are products of families that fail to take care of their children (Female, older generation).

An in-depth interviewee reacted to the notion that children can become wayward if their parents fail to meet their responsibilities:

It is rare to find someone who will bear many children and raise them up properly. If one decides to bear many children, one would have to make provision to take care of them from the beginning so that those children do not become wayward (omokómo) (Male, younger generation).

A key informant buttressed the idea that failure to provide for children will hinder their good character:

Considering the fact that it is very difficult to raise children these days in terms of financial constraints, one has to be very careful. If there is no money to take care of them, those children can become wayward (Female, middle-aged).

\subsection{Children's education as a check against increasing fertility}

The need for formal education for children was found to be a major responsibility that limited fertility. This need was very noticeable in participants' representation of the pecuniary challenge regarding fertility reduction. It was expressed intensely and pervasively. A group discussant stated when recounting motivations of fertility:

The responsibilities we have on our shoulders are now many. Back then, parents did not send their children to school (any child that goes to school then was seen as a lazy fellow) but that is not the case today because education has become very important. Parents do not want their children to become servants to their mates just because they failed to send them to school (Male, older generation). 
Ibrahim: The role of financial obligations in fertility change among Yorùbá farmers of southwestern Nigeria

Other group discussants also recounted the uncomplicated nature of needs in the past and the huge need for funding children's schooling in current times:

During our time, what was paramount to our parents was merely to feed us. These days, we are suffering; we toil almost exclusively for our children because of exorbitant school fees. That is why it is very hard to take proper care of many children these days. You just have to have the number you can take care of (Male, middle-aged).

The Yorùbá are great lovers of western formal education and parents are under pressure to invest in their children's education. An in-depth interviewee lent her voice to this position while stating her resolve:

People now give birth to the number of children they can afford to give quality education and also cater for other needs. To give quality education to my children, I just have to mind the number of children I have (Female, younger generation).

Another in-depth interviewee expressed the difficulty of funding formal education while comparing her situation with what was obtained in the past:

Unlike in those days when there was no access to formal education, we now have the responsibility of sending our children to school and taking care of every other responsibility for them. So it is very difficult to bear many children these days (Female, middle-aged).

When confronted with the question of childbearing and the need to finance children's education, a key informant said:

The summary of all is that the rising cost of education and child upbringing has discouraged many people from having many children. And if you care for one child at the expense of others, you are creating enmity among the children. These have caused many changes to the rate of childbearing in our society (Male, older generation).

Another key informant identified an alternative to formal education but still expressed the need for formal education and limiting fertility in contemporary times: 
Those that are unable to train all their children in school make them learn a trade or vocation. But there is no one who would not love to give formal education to his or her children. That is why there is so much emphasis on having few children these days. May God help us all (Male, middle-aged).

\subsubsection{Civilization-induced need for formal education}

A civilization-induced need for formal education is a sub-theme of children's education as a check against increased fertility and featured extensively in participants' contributions. In everyday language, civilization (òlàjú) expresses the enormous changes that have taken place as a result of colonialism and European contact. A group discussant stated:

Now that civilization is here, people have become aware of the fact that having many children will prevent them from providing proper care, especially giving them quality education, unlike in our time when we did not have such luxury because our parents did not consider education a priority. The main focus of parents back then was just to feed us. No formal education for us, and food was not a problem. There were a lot of crops on the farm for consumption (Female, older generation).

An in-depth interviewee similarly discussed the role of civilization in childbearing:

Well, we can say civilization is the cause. To raise children these days is so expensive. If not for the grace of God, things will be difficult. Sending them to school and giving them what they want requires a lot of money. Only someone who is wealthy can give birth to any number of children he or she wants. But we that are of the lower class, the number must be limited so that we can raise them well with the resources we have (Male, middle-aged).

A key informant emphasized the influence of civilization on the need for formal education and reduced fertility:

Education, which many of us did not have access to, has now become compulsory in this civilized era. Therefore, any parent who wants to give birth to many children will first consider the financial implications of giving the children a sound education. This shows that civilization, which thrives on education, has ruined many of our traditions (Male, older generation). 


\subsubsection{The dynamic of public versus private school in the educational constraint on increased fertility}

The dynamic of public versus private school is another sub-theme of children's education as a check against increasing fertility. Participants expressed various thoughts regarding considerations of school ownership, quality, and affordability in fertility decisions. A group discussant stated:

My capability to fend for my children is important, especially the type of school they attend. If I can afford a public school, fine, but that is not what I will like. Even tuition in public schools is high and comparable to that of some private schools. So, one just has to be wary of educational cost in deciding to have additional children (Female, younger generation).

The demand of paying school fees is so heavy that it is reflected in people's fertility decision-making. An in-depth interviewee responded similarly when answering a question regarding finances, children's education, and childbearing:

The summary of all is that the rising cost of education and child upbringing has discouraged many people from having many children. If you enrol one child in public school at the expense of another, you will create enmity among the children, though public schooling also costs big money. This has caused many changes to the rate of childbearing in our society (Male, older generation).

Public schools have the reputation of not providing the quality education that allows students to compete with their counterparts from other parts of the world. A key informant buttressed the idea that public school attendance is becoming an unattractive choice and this induces the need for reduced fertility:

The choice of government school is like suffering (iyà ni ilewé ijọba). If you want the best for children then you will strive to take them to private schools. These situations prevent us from being able to demonstrate our love for having children. If government is upright, if they provide good schools and there is enough food around, then I will have more children certainly (Male, middleaged). 


\subsection{Women's financial obligations and fertility reduction}

While so far there has been little difference between male and female representations of financial obligation and fertility reduction, certain additional issues were expressed exclusively by female participants. These include domestic economic responsibilities, a dearth of support from husbands, and husband-related obligations.

\subsubsection{Domestic economic responsibilities}

Among the female participants the topic of domestic economic responsibility stood out. In most cultures the domestic sphere is typically the domain of women, so it is unsurprising that female participants raised special concerns. A group discussant expressed concern about the ability to feed children:

Responsibilities play a lot of roles in childbearing. One major responsibility is feeding the children. It is mandatory to give one's children a good nourishing meal for them to grow very well, but if the children are many it would be impossible to feed them properly. Many of them would only be undernourished (Female, younger generation).

An in-depth interviewee expressed concern about clothing needs:

Apart from the feeding, clothing too is important. We can hardly buy new clothes for our children while we face the problem of paying to sew fabrics for them too. And our children will not want to wear fairly used clothes. So, that is why bearing many children these days is not advisable. It makes no sense anymore (Female, middle-aged).

The yuletide is a period that people, especially children, look forward to because it is associated with having treats. A key informant expressed financial obligation in fertility reduction by focusing on economic demands during the yuletide:

During the yuletide, the burden is more on us to ensure we beautify the house, plan special dishes, and buy other beautiful things. The men will always grumble and you will not want your own children to be sad because they are not provided for. It is incumbent upon any reasonable woman to be especially concerned about the number of children she can care for (Female, older generation). 


\subsubsection{Dearth of support from husbands}

Several female participants were quick to express husbands' inattention to children's economic needs, which women can hardly ignore. Some female participants were concerned about physical and financial care during pregnancy. A group discussant stated:

What we need to consider in having many children is the responsibilities attached to it. There is no one that does not love children. We all love children dearly. What could make a woman not want additional children is the responsibility involved. You know, when a man impregnates a woman, the woman is left to carry the pregnancy about until she delivers the baby. And even then, the woman could be left to fend for herself if the man has no money (Female, younger generation).

Men are normatively responsible for women's welfare, but this cannot be taken for granted, especially among the Yorùbá where women have a reputation for being highly enterprising. An in-depth interviewee lamented:

Among important factors to consider is the husband's support for the wife. There are many women who are married yet they live like single mothers. Many men are too irresponsible in the family. So many women think about these things and want to limit the number of childbirths they want to have (Female, middle-aged).

A key informant similarly asserted:

The roles are many in childbearing. Starting from the pregnancy stage, we face a lot of responsibilities up to the time of delivery. I was responsible for buying virtually all my babies needed. It continued to the time when they started schooling when we need to foot their tuitions. It is really tasking but I had to keep paying because I do not want them to be wayward thereafter (Female, older generation).

\subsubsection{Husband-related obligation}

Apart from a dearth of support from husbands, many female participants expressed that women are responsible for their husbands. This is atypical of Yorùbá marital norms, but 
even in precolonial times marital relationships were fluid, and support can flow in both directions. A group discussant stated:

It is even a bigger problem for us to bear many children. We carry pregnancy and when men can bone-faced lie that they do not have money, we cannot. It is not possible for us to abandon the children when they are hungry, the way our men can do so easily and go drink with their friends. Many times, we cater for our husbands. We take care of heavy school bills, buying food, buying drugs, and so many little purchases in the household (Female, middle aged).

In a response to the question of important factors to consider in fertility decisionmaking, an in-depth interviewee asserted:

These days we cater for our husbands too, along with our children. This happens whenever our husbands do not have money to give us for upkeeping. We are to foot the bill for feeding expenses and other items (Female, younger generation).

A key informant recounted a lived experience that supported the idea that women who have to carry their husbands are motivated to reduce their fertility:

Nowadays, any parent who wants to give birth to many children will first consider the financial implications and other factors. I once told my daughter to go for family planning when her husband was becoming irresponsible and irritating. My daughter was looking older for her age when she would toil to take care of her children and even her husband. (Female, older generation.)

\section{Discussion}

The pecuniary motivation for fertility change is highly instructive. Participants construed financial obligations, epitomized as bùkáàtà (responsibilities) and ojúse (duties), as impediments to increased fertility. A middle-aged male participant remarked: "I have no personal reason to stop having children except that I do not have money to take care of them". In essence, fertility is being adapted to current socioeconomic circumstances, vindicating the Caldwellian theory of wealth flows. According to Caldwell (1976), fertility responds to economic gains. Where there is no gain in decreased fertility, fertility will be unabated. Where there is economic gain in decreasing fertility, fertility will be restricted. Increased wealth flows from parents to children, as parents record the huge expense of raising children. Continuous fertility 
calls for financial obligations that are reduced when fertility is restricted. Thus, restricted fertility is a form of economic gain, especially where children no longer serve as farm labour (Ibrahim 2020). This is rationality! It is very interesting that such an intense pecuniary motivation for fertility change was pervasively expressed among a group of farmers in a sub-Saharan African region, a region housing most of the fortyeight countries earmarked as least developed countries (LDCs) (United Nations Population division 2015). The presupposition in demographic transition theory that socioeconomic development triggers fertility transition is therefore very limited. This vindicates Bongaarts's (2017) position that Africa's fertility transition was "earlier". Bongaarts (2017) came to this conclusion after questioning the uniqueness of Africa's demographic transition compared with transitions in other developing countries: at the beginning of fertility transition sub-Saharan Africa was less developed than when juxtaposed with developmental status at the kickoff of the transition in other developing countries. Bongaarts's (2017) position also confirms Caldwell's (1981) assertion that "though fertility remains high in many contemporary Third World countries, a sustained decline may well begin without having to await further fundamental economic change" (p. 5). The demographic transition theory is also limited in its assumption of what rationality entails. Rationality is not the birth right of any one people but a basic human attribute.

The strong drive for fertility change among Yorùbá farmers is consistent with demographic data for Nigeria. As noted in the introduction, Yorùbá people belong to the southwest, one of the six geo-political regions in Nigeria. The region has the highest total demand for family planning, lowest average household size, and the lowest total fertility rate (TFR) of 3.9. Although this TFR is far above the world TFR of 2.46 (United Nations Population Fund 2019), it nevertheless shows that the Yorùbá are at the forefront of fertility change in Nigeria. The south-south and southeastern Nigerian regions have the second- and third-lowest TFRs, at 4.0 and 4.7 respectively (National Population Commission 2019). Thus, the Yorùbá are not alone in the drive towards fertility change in Nigeria. In his anthropological report of demographic motivations among the Igbo-speaking people of southeastern Nigeria, Smith (2004) writes that it was astounding to find that people "talked constantly about the pressures to have fewer children. The majority of married men and women in their childbearing years recognized and articulated the need to plan and limit the number of children they would have" (p. 227). Smith (2004) finds that this is a reflection of unique and distinct population dynamics, "different from the dominant popular Western tropes that tend to depict fertility transition as part of a grand process of "progress," "modernization," and "development" (p. 227).

The theme of scriptural justification for pecuniary considerations in childbearing is a paradox. Scriptural references have typically been used to justify high fertility. 
McQuillan (2004) asserts that of all social institutions, religion dictates the moral codes that direct human behaviour, and "broadly speaking, specific rules designed to directly influence the proximate determinants of fertility are most typical of 'the religions of the book': Judaism, Christianity, and Islam [...] all three religious traditions have supported restrictions on at least some of these practices" (p. 27). Similarly, Norris and Inglehart (2004: 23) assert that "one of the most central injunctions of virtually all traditional religions is to strengthen the family, to encourage people to have children, to encourage women to stay home and raise children". Indeed, religions have always been in favour of high fertility. The favourable disposition of these religions has aided Africa's traditional high valuation of fertility and has produced high fertility outcomes for the region. The open nature of Yorùbá traditional religion facilitated the wide acceptance of Christianity and Islam when they were introduced into Yorùbáland, and many Yorùbá identify themselves as Muslims or Christians. The finding of scriptural justification for pecuniary consideration in fertility is therefore paradoxical, to say the least. It substantiates the theory that people use scripture to justify thoughts and actions: Fertility change appears inevitable once people are motivated by rational reasons, and when this happens religion loosens its hold and scriptural evidence is sought to justify the desired end. This finding shows that the fertility transition advances in human societies irrespective of religious inhibitions. In his Presidential Address Delivered At The General Conference Of The International Union For The Scientific Study Of Population, Beijing, Caldwell (1997: 811) justified "the need for a unifying theory of fertility transition". He proclaimed:

... the supposedly spontaneous Western fertility transition ... certainly did not happen as soon as the economic calculus was right... fertility decline was preceded by an intellectual battle... Ideological debate and the intervention of activists were important in the first, or Western fertility decline, as they were to be in the second, or contemporary third world decline...The battle for birth control was won through secular change, ... It was a rolling back of religion's grip on - indeed, concentration on - sexuality, or an ignoring of the religious view. It was a legitimation of sexual activity not aimed at procreation and specifically of the use of methods to prevent conception (pp. 804-806, italics mine).

This is not to jettison the influence of religion on fertility. For instance, Muslims are notably responsible for higher fertility figures in developing countries, but recently Muslim fertility has reduced substantially in certain contexts (Jones 2006). The paradoxical scriptural justification for pecuniary consideration in fertility change among the participants implies that the traditional role of religion in fertility change is not 
sacrosanct. Furthermore, Yorùbá farmers manifest the capacity to deploy scriptural justifications in line with desired changes in fertility.

The justification of fertility reduction on the basis that inability to meet financial obligations will inhibit children's good character is instructive. It reinforces earlier findings on the pecuniary motivation for fertility change, but further localises this motivation. Yorùbá people say that tori omo n'mo fi'nsisẹ (I work because of children). They also say that bí a ko bá tó baba omoo șe, a kí pe alákàrà (if one is not man enough to father a child, one should not summon a seller of ákàrá $\dot{a}^{3}$ ). This proverb is typically used to stress the lesson that one should not go beyond one's means to achieve certain ends. 'Tó baba omoo șe', i.e., 'being man enough to father a child' is used in this context to represent financial standing. However, the phrase buttresses the cultural expectation that men in particular should take financial responsibility for their child or children. The Yorùbá proverb àgbàká laabiyamo ńgbàjá mo omo re (a parent should secure her or his child absolutely) further buttresses the Yorùbá expectation that one must bear one's parental responsibility diligently. Mothers are typically referred to as abiyamo, but the nomenclature is also applied to caring fathers or someone who has borne a lot of children. These are all strong indications that the centrality of children's needs is recognized and applauded in Yorùbá culture. This is not unconnected with the Yorùbás' traditional love for children. In a study of Orìsà worship and other motivations in Yorùbá society, Barber (1981) asserts that "paramount among the blessings people desire is children; after that come wealth, health and long life" (p. 735). Omobowale, Omobowale, and Falase (2019: 6) also assert that "children are more important than wealth or material success", and that "children occupy a strategic space among the Yorùbá. Children are critical for societal continuity, but such children must be properly socialised, and be psychologically and economically equipped to responsibly function within the society.... As much as it is honourable to have children ... (it is equally honourable) to ensure a child is raised to become responsible" (p. 3, bracket mine). The theme that inability to meet financial obligations will inhibit children's good character underscores the Yorùbá drive to spare nothing to produce an upstanding child, or omolúàbí. The subject of omolúàbi is so central to Yorùbá social life that a parent whose child is not describable as such is bound to experience some measure of shame. The omolúábi ideology is an established basis for asserting the worth of the individual that every responsible parent will want his or her child to become. To become omolúàbi and deserving of societal approval, children must demonstrate ì $\grave{a}$ (good character). This is what counts in defining the ideal personality, as discussed in the introduction. Owing to the defenceless character of children, parents and other responsible adults owe them a duty of care, including providing for their needs. It is apt that the participants were not indifferent to the financial constraints on

\footnotetext{
${ }^{33}$ Ákàrà is a food made by frying seasoned bean paste.
} 
raising children in modern times, and it is laudable that they were willing to reduce fertility accordingly. The theme justifying fertility reduction on the basis of the fear that inability to meet financial obligations will prevent a child's good character emphasizes elements of Yorùbá cultural motivation.

The findings also reveal that the need for formal education is an intensely and pervasively expressed major fertility-limiting factor. This accurately reflects socioeducational dynamics in Yorùbá society. Owing to the introduction of western education in the $19^{\text {th }}$ century and the policy of free education in the 1950 s, western education became culturally construed as a valuable phenomenon in Yorùbáland (Omobowale, Omobowale, and Falase 2019). Western education emerged as a mechanism of social mobility, leading to the social construction of education as an instrument of positive life transformation. Western education is so valued among the Yorùbá that parents who cannot afford to pay for it seek ways of having their children live with extended family members who take responsibility for the child/children's education in exchange for domestic chores (ibid). This explains the southwest region's educational profile, as reviewed in the introduction. Further, in southwestern Nigeria, $94.6 \%$ of male and $95.8 \%$ of female children aged 5-14 years attend school. Of these, $57.5 \%$ of male children and $62.9 \%$ of female children attend private schools and $42.5 \%$ of male children and $36.7 \%$ of female children attend public schools (National Bureau of Statistics 2019). In addition, of Nigerian's six regions the Yorùbá region spends the most on children's education. A recent national survey (National Bureau of Statistics 2019) shows that the average annual total expenditure per child for primary schooling in Nigeria is $\mathrm{N} 20,504$ (\$53.96). This expenditure is highest in the southwest ( $\mathrm{N49,593}$

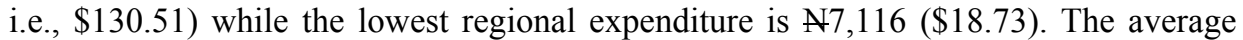
annual total school expenditure per child for secondary schooling in Nigeria is N47,879

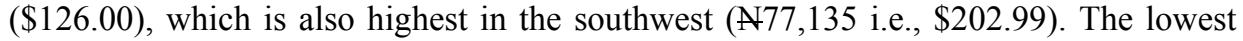
expenditure across the other regions is $\$ 24,366$ (\$64.12) (National Bureau of Statistics 2019 , conversion to $\$$ equivalent mine at the rate of $1 \mathrm{USD}=380.00 \mathrm{NGN})$. The high cost of educating the average child, especially in southwestern Nigeria, is a motivation for fertility change. People are under pressure to spend on education because western education has become culturally valuable.

Interestingly, participants recounted the influence of civilization (òlàjú) on the monetary need for western education. This is apposite because traditional Yorùbá education is free. The Yorùbá often cite civilization as causing change in elements of their culture (Ibrahim and Jegede 2017). This 'civilization' is describable as western contact (Olurode and Olusanya 1994; Lawal 2001). Issues relating to public versus private school were another salient feature of findings regarding children's education and fertility change. "In Nigeria the quality of education is often associated with how much a parent has to pay" (Babalola 2018: 199), and payment often depends on 
whether the school is privately or publicly owned. Public schools are typically far cheaper than private schools, though there are very cheap private schools that offer educational services in a less-than-humane school environment. The dynamic of public versus private school in children's education and fertility change emphasizes the way the Yorùbá value western education - and also Yorùbá farmers' rational approach to fertility.

The findings reflect the peculiarities of economic obligations regarding fertility change that disfavour women. Women participants were especially concerned with domestic issues like feeding, clothing, and Christmas/Sallah preparations. Several female participants bemoaned the dearth of support from husbands and the obligations to husbands that they have to put up with. A grandmother protested: "I once told my daughter to go for family planning when her husband was becoming irresponsible and irritating. My daughter was looking older for her age when she would toil to take care of her children and even her husband". These findings are contrary to cultural expectations. Most African cultures, including the Yorùbá, are strictly patriarchal, and therefore stipulate masculine breadwinners. A man is expected to provide all his family's needs. However, as noted in the introduction, this is hardly the case in reality. The erosion of traditional family values (Akanle, Adebayo, and Busari 2014) and the prevailing high level of poverty that has impoverished many families have contributed immensely to men's neglect of traditional obligations. Women are then typically left to bear the brunt of catering for their children. Yorùbá women are typically enterprising and this may contribute to the dearth of support from husbands and women having to support husbands. For instance, they sustain traditional crafts, earn a living, and pay tuition for their children (Akinbogun and Ogunduyile 2009). Even in precolonial times Yorùbá women "occupied a significant place in political organization, religion, family life, and the economy" (Denzer 1994: 2). Women may unilaterally amass riches, construct houses, and be benevolent to others. Caldwell, Orubuloye, and Caldwell (1991: 238) stated that "Yorùbá women enjoyed a good deal of independence in the outside world". They engage widely in trade and polygyny enables them to focus on their businesses while the "husband benefits from their wealth and even takes loans from them" (Ibid: 235). Indeed, the economic demands behind fertility change that apply specifically to women are an interesting basis for further study.

\section{Conclusions}

This article focuses on the change towards low fertility among Yorùbá farmers, thereby vindicating the Caldwellian theory of wealth flows. Economic demands are a major driving force behind fertility and demonstrate the rational and adaptive character of 
Yorùbá farmers in the current social climate. This driving force runs contrary to demographic transition theory, which expects economic wherewithal to drive fertility change. The work reported here exposes the limitations of demographic transition theory through the localised exploration of demographic motivations. It is apposite to consider emic perspectives in the construction of mainstream knowledge. Seeking to accommodate local attitudes, behaviours, and other specific adaptive entities can further enhance advances in social science literature. This paper presents a paradoxical scriptural justification for pecuniary considerations in fertility change, indicating that religion is not sacrosanct in fertility matters. Anxiety that the inability to meet monetary obligations will prevent the development of children's good character motivates reduced fertility, localising monetary concerns in fertility decisions and accentuating strong elements of Yorùbá culture. The need for formal education is a major fertilitylimiting factor that reflects sociocultural and historical educational dynamics in Yorùbá society. These dynamics lie behind the value that the Yorùbá ascribe to western education and the rational economic demand approach to fertility decision-making. Some economic demands in fertility change are peculiar and disadvantageous to women, reflecting the erosion of traditional family values and abetted by the prevailing high level of poverty and the enterprising nature of Yorùbá women. 


\section{References}

Abímbọlá, W. (1975). İwàpẹlẹ: the concept of good character in Ifá literary corpus. In: Abímbọlá, W. (ed.). Yorùbá oral tradition. Ifẹ: Department of African Languages and Literatures: 387-420.

Abímbọlá, W. (2004). Àwọn ojú odù mẹèèrìndínlógún. Ibadan: UP PLC.

Adebisi, A. (2016). Yoruba traditional education philosophy in the evolution of a 'total man'. International Journal of Humanities and Cultural Studies 2(2): 33-45.

Adogame, A. (2000). Aiye loja, orun ni le: the appropriation of ritual space-time in the cosmology of the Celestial church of Christ. Journal of Religion in Africa 30(1): 3-29. doi:10.1163/157006600X00465.

Afonja, S. (1981). Changing modes of production and the sexual division of labor among the Yorùbá. Signs 7(2): 299-313. doi:10.1086/493883.

Akanle, O., Adebayo, A.O., and Busari, D. (2014). The absentee spouse phenomenon and spousal coping strategies in Ibadan, South-Western Nigeria. African Population Studies 27(2): 411-423. doi:10.11564/27-2-485.

Akinbogun, T.L. and Ogunduyile, S.R. (2009). Crafts engagement in the economic survival of South-Western Nigerian rural women. Journal of Enterprising Communities: People and Places in the Global Economy 3(2): 217-234. doi:10.1108/17506200910960897.

Awoniyi, T.A. (1975). Omoluabi: The fundamental basis of Yoruba education. In: Abímbọlá, W. (ed.). Yoruba oral tradition. Ife: Department of African Languages and Literature, University of Ife: $357-388$.

Babalola, S. (2018). Inequalities within Nigeria's education system: A focus on secondary schools in Lagos, Ondo State and Ogun state. Education in Modern Society 16: 196-202.

Barber, K. (1981). How man makes god in West Africa: Yoruba attitudes towards the Orisa. Africa 51(3): 724-745. doi:10.2307/1159606.

Bledsoe, C.H. (2002). Contingent lives: Fertility, time, and aging in West Africa. Chicago: University of Chicago Press. doi:10.7208/chicago/9780226058504. 001.0001 .

Bongaarts, J. (2017). Africa's unique fertility transition. Population and Development Review 43(S1): 39-58. doi:10.1111/j.1728-4457.2016.00164.x. 
Caldwell, J.C. (1976). Toward a restatement of demographic transition theory. Population and Development Review 2(3/4): 321-366. doi:10.2307/1971615.

Caldwell, J.C. (1981). The mechanisms of demographic change in historical perspective. Population Studies 35(1): 5-27. doi:10.2307/2174833.

Caldwell, J.C. (1997). The global fertility transition: The need for a unifying theory. Population and Development Review 23(4): 803-812. doi:10.2307/2137380.

Caldwell, J.C., Orubuloye, I.O., and Caldwell, P. (1991). The destabilization of the traditional Yoruba sexual system. Population and Development Review 17(2): 229-262. doi:10.2307/1973730.

Capone, S. (2018). Yoruba religion. In: Gooren, H.P.P. (ed.). Encyclopedia of Latin American religions. Cham: Springer Nature. doi:10.1007/978-3-319-089560 561-1.

Carlson, E. (2019). Reformulating second demographic transition theory. In: Schoen, R. (ed.). Analytical family demography. Cham: Springer Nature. doi:10.1007/9783-319-93227-9_2.

Cleland, J. and Machiyama, K. (2017). The challenges posed by demographic change in sub-Saharan Africa: A concise overview. Population and Development Review 43(S1): 264-286. doi:10.1111/padr.170.

Cleland, J., Onuoha, N., and Timæus, I. (1994). Fertility change in sub-Saharan Africa: a review of the evidence. In: Locoh, T. and Hertrich, V. (eds.). The onset of fertility transition in sub-Saharan Africa. Liège: Derouaux Ordina: 1-20.

Cleland, J. and Wilson, C. (1987). Demand theories of the fertility transition: An iconoclastic view. Population Studies 41(1): 5-30. doi:10.1080/003247203100 0142516.

Coast, E.E., Hampshire, K.R., and Randall, S.C. (2007). Disciplining anthropological demography. Demographic Research 16(16): 493-518. doi:10.4054/DemRes. 2007.16.16.

Cooper, B.M. (2019). Countless blessings: A history of childbirth and reproduction in the Sahel. Bloomington: Indiana University Press. doi:10.2307/j.ctvj7wmzr.

Denzer, L. (1994). Yoruba women: a historiographical study. The International Journal of African Historical Studies 27(1): 1-39. doi:10.2307/220968.

Drewal, H.J., Pemberton III, J., and Abiodun, R. (1989). Yorùbá: Nine centuries of African art and thought. African Arts 23(1): 68-77+104. doi:10.2307/3336802. 
Dyson, T. (2010). Population and development: The demographic transition. London: Zed Books.

Elegbeleye, O.S. (2005). The Yorùbá personality assessment criteria. Studies of Tribes and Tribals 3(2): 85-91. doi:10.1080/0972639X.2005.11886523.

Fadipe, N.A. (1970). The sociology of the Yorùbá. Ibadan: Ibadan University Press.

Galor, O. (2004). The demographic transition and the emergence of sustained economic growth. Working Paper 2004-13. Providence: Brown University, Department of Economics. doi:10.2139/ssrn.594521.

Gareau, F.H. (1988). Another type of third world dependency: The social sciences. International Sociology 3(2): 171-178. doi:10.1177/026858088003002005.

Gitahi, G. (2017). An African-driven health agenda. Lancet 390(10090): 96. doi:10.10 16/S0140-6736(17)31804-4.

Harris, M.D. (1992). Africentrism and curriculum: Concepts, issues, and prospects. The Journal of Negro Education 61(3): 301-316. doi:10.2307/2295250.

Ibrahim, F.M. (2020). Tracking agriculture-induced fertility among Yorùbá farmers of southwestern Nigeria. Issues in Ethnology and Anthropology 15(2): 533-549. doi:10.21301/eap.v15i2.9.

Ibrahim, F.M. and Jegede, A.S. (2017). Tradition and limits: Polemical construction of body size among the Yoruba of southwestern Nigeria. Journal of African American Studies 21(2): 236-255. doi:10.1007/s12111-017-9360-x.

Jones, G.W. (2006). A demographic perspective on the Muslim world. Journal of Population Research 23(2): 243-265. doi:10.1007/BF03031818.

Kandiyoti, D. (1988). Bargaining with patriarchy. Gender and Society 2(3): 274-290. doi:10.1177/089124388002003004.

Kertzer, D. (1997). The proper role of culture in demographic explanation. In: Jones, G.W., Douglas, R.M., Caldwell, J.C., and D'Souza, R.M. (eds.). The continuing demographic transition. Oxford: Oxford University Press: 137-157.

Kirk, D. (1996). Demographic transition theory. Population Studies 50(3): 361-387. doi:10.1080/0032472031000149536.

Lawal, B. (2001). Aworan: representing the self and its metaphysical other in Yoruba art. The Art Bulletin 83(3): 498-526. doi:10.2307/3177240. 
McIntosh, M.K. (2009). Yorùbá women, work, and social change. Bloomington: Indiana University Press.

McQuillan, K. (2004). When does religion influence fertility? Population and Development Review 30: 25-56. doi:10.1111/j.1728-4457.2004.00002.x.

National Bureau of Statistics (2019). LSMS Integrated Surveys on Agriculture: Nigeria General Household Survey Panel, Wave 4 (2019) [electronic resource]. Nigeria: National Bureau of Statistics. https://www.nigerianstat.gov.ng/download/1030.

National Population Commission (NPC) [Nigeria] and ICF. (2019). Nigeria Demographic and Health Survey 2018. Abuja and Rockville: NPC and ICF.

Norris, P. and Inglehart, R. (2004). Sacred and secular: Religion and politics worldwide. New York: Cambridge University Press. doi:10.1017/CBO97805 11791017.

Okolie, V.O., Cisana, S., Schanfield, M.S., Adekoya, K.O., Oyedeji, O.A., and Podini, D. (2018). Population data of 21 autosomal STR loci in the Hausa, Igbo and Yoruba people of Nigeria. International Journal of Legal Medicine 132(3): 735737. doi:10.1007/s00414-017-1722-3.

Olademo, O. (2009). Gender in Yorùbá oral tradition. Lagos: Concept Publications Limited, Centre for Black and African Arts and Civilization.

Olurode, L. and Olusanya, P. O. (1994). Nigerian heritage: The Yoruba example. Lagos: Rebonik Publications.

Omobowale, A.O. (2008). Clientelism and social structure: an analysis of patronage in Yorùbá social thought. Afrika Spectrum 43(2): 203-224.

Omobowale, A.O. (2013). Guest editor's introduction. International Journal of Sociology 43(1): 3-7. doi:10.2753/IJS0020-7659430100.

Omobowale, A.O., Omobowale, M.O., and Falase, O.S. (2019). The context of children in Yoruba popular culture. Global Studies of Childhood 9(1): 18-28. doi:10.11 $77 / 2043610618815381$.

Ostien, P. (2012). Percentages by religion of the 1952 and 1963 populations of Nigeria's present 36 States. Oxford: Nigeria Research Network (NRN), Oxford Department of International Development (NRN Background Paper 1).

Renne, E.P. (1993). Gender ideology and fertility strategies in an Ekiti Yorùbá village. Studies in Family Planning 24(6): 343-353. doi:10.2307/2939244. 
Smith, D.J. (2004). Contradictions in Nigeria's fertility transition: The burdens and benefits of having people. Population and Development Review 30(2): 221-238. doi:10.1111/j.1728-4457.2004.011_1.x.

United Nations Population Division (2015). World population prospects: The 2015 revision, key findings and advance tables. New York: Department of Economic and Social Affairs, United Nations (Working Paper ESA/P/WP.241). doi:10.18 356/b793d926-en.

United Nations Population Division (2017). World population prospects: The 2017 revision, key findings and advance tables. New York: Department of Economic and Social Affairs, United Nations (Working Paper ESA/P/WP/248). doi:10.18 356/b19523c6-en.

United Nations Population Division (2019). World Population Prospects: The 2019 Revision. New York: Department of Economic and Social Affairs, United Nations. doi:10.18356/be6ccd17-en.

United Nations Population Fund (2019). State of world population 2019. New York: Department of Economic and Social Affairs, United Nations.

Waterman, C.A. (1990). Our tradition is a very modern tradition: Popular music and the construction of pan-Yorùbá identity. Ethnomusicology 34(3): 367-379. doi:10.2307/851623. 